\title{
Liberalismo, Justiça Social e Responsabilidade Individual*
}

\author{
Álvaro de Vita
}

Professor titular do Departamento de Ciência Política da Universidade de São Paulo (USP).

São Paulo, Brasil (e-mail: alvaro_vita@uol.com.br)

\section{INTRODUÇÃO}

$\mathrm{O}$

propósito deste artigo é examinar o debate normativo contemporâneo sobre a justiça socioeconômica, assumindo, como não poderia deixar de ser, uma posição específica e controversa nesse debate, que corresponde àquilo que denomino liberalismo igualitário (Vita, 2007; 2008). Além de expor o modo como entendo essa posição, vou contrastá-la com duas perspectivas normativas não igualitárias e com uma terceira que, com base em uma delimitação menos estrita do que aquela que aqui adotarei, pode ser também considerada uma variante de liberalismo igualitário, apresenta, contudo, uma interpretação significativamente distinta das aspirações normativas do igualitarismo. Serão examinados os méritos relativos do liberalismo igualitário em contraste com uma teoria política liberal anti-igualitária, o "libertarianismo" , e, a seguir, em contraste com uma perspectiva normativa sobre questões de disparidades socioeconômicas que não constitui pro-

\footnotetext{
* Uma versão inicial deste artigo foi apresentada no concurso para professor titular que prestei na Universidade de São Paulo (USP) em agosto de 2011. Gostaria de agradecer os comentários que então foram feitos pelos membros da banca examinadora, constituída pelos professores Renato Lessa, Celso Lafer, Marco Aurélio Nogueira, Gabriel Cohn e Maria Hermínia Tavares de Almeida, e que tiveram por objeto a agenda de pesquisa na qual este artigo se insere. Gostaria de também agradecer os comentários e sugestões de dois pareceristas anônimos de DADOS, que me empenhei, embora talvez não tenha conseguido lhes fazer justiça inteiramente, para levar em conta.
}

DADOS - Revista de Ciências Sociais, Rio de Janeiro, vol. 54, n-4 4, 2011, pp. 569 a 608. 
priamente uma teoria política, e sim uma posição não igualitária associada à defesa de um padrão de suficiência. Contra esta posição, serão expostas razões pelas quais devemos nos preocupar não somente com a abolição da pobreza, mas também com desigualdades relativas. Por fim, o contraste será com uma modalidade de igualitarismo que vem sendo denominado, na literatura teórica recente sobre justiça distributiva, luck egalitarianism.

Não há como considerar, neste artigo, todas as posições que se apresentam no debate normativo sobre disparidades socioeconômicas. Mas é possível, mediante o confronto com algumas dessas posições, esclarecer o modo pelo qual o liberalismo igualitário interpreta a justiça social em uma sociedade democrática e, em particular, precisar o tratamento que uma visão igualitária deve dispensar à responsabilidade individual, uma temática que costuma ser apropriada pela linguagem política conservadora.

Historicamente, o liberalismo constitui um dos paradigmas dominantes na proposição e na justificação de princípios políticos normativos. Mas há diferentes formas de liberalismo e diferentes componentes fundamentais em cada uma delas. Examinando formas de liberalismo que têm proeminência na teoria política contemporânea, a discussão que vem a seguir irá se desenvolver em dois planos distintos. No primeiro, colocando em questão o componente de justiça distributiva de diferentes liberalismos contemporâneos, salientarei as razões que temos para defender certa interpretação do igualitarismo contra perspectivas normativas anti ou não igualitárias. No segundo, o esforço será o de mostrar que essa interpretação valoriza a responsabilidade individual, mas de um modo que, diversamente do luck egalitarianism (como espero evidenciar), não faz nenhuma concessão à crítica conservadora segundo a qual o igualitarismo deve ser rejeitado porque "corrói o caráter individual", ao não recompensar o esforço consciencioso e ao premiar (com transferências compensatórias) aqueles que não são "merecedores"1.

\section{POR QUE A DESIGUALDADE IMPORTA}

Liberalismo, como outros termos centrais do nosso vocabulário político, não tem um significado consensualmente compartilhado no modo como é empregado na teoria política e na discussão pública. Se o que está em questão é a justiça social e política, há duas vertentes teóricas 
do liberalismo contemporâneo que contrastam de forma nítida. Antes de contrastá-las, cabe apontar uma ideia que, formulada de modo genérico, é compartilhada por ambas as vertentes.

Um Estado liberal justo deve ter como um de seus objetivos centrais propiciar a seus membros as condições para que cada um possa agir com base em suas próprias conviç̧ões sobre aquilo que tem valor intrínseco na vida. De acordo com essa visão, não cabe à autoridade política determinar que objetivos e fins - quer isso diga respeito a ideais morais, religiosos ou políticos ou ao bem e à felicidade individuais - as pessoas devem se empenhar em realizar em suas vidas. O exercício do poder político, que sempre envolve o emprego da coerção coletiva da sociedade, não pode se justificar com base na suposição de que há uma doutrina verdadeira, quer se trate de uma religião ou de uma doutrina moral ou política, sobre o que constitui a boa vida para o homem e à qual os que estão submetidos a esse poder devem se conformar. Dispor de soberania para determinar que conviç̧ões de valor moral devem guiar as próprias escolhas em um âmbito de independência individual preservado de interferências arbitrárias é aquilo que, para qualquer vertente de liberalismo político, responde pela ideia de liberdade. A primeira formulação dessa visão, ainda que não despida de ambiguidades (o termo liberalismo só se incorporou definitivamente ao vocabulário político ocidental na segunda metade do século XIX), é a que se encontra na Carta acerca da tolerância (de 1689), de John Locke. E essa é essencialmente a visão que vamos encontrar nas obras políticas de uma longa linhagem de pensadores que contribuíram para o liberalismo político, como Montesquieu, Kant, Benjamin Constant, Tocqueville e Stuart Mill.

Mas como entender as condições que, sob um Estado liberal justo, capacitam cada pessoa a viver de acordo com suas próprias convicções de valor moral? A resposta a essa questão é responsável pela delimitação de posições no campo do liberalismo político contemporâneo. Uma delas vem sendo designada pelo neologismo "libertarianismo" e está associada a teóricos políticos como Friedrich Von Hayek e Robert Nozick. O valor político central, para essa vertente, é uma noção de "liberdade negativa" - o termo foi cunhado por Isaiah Berlin em seu clássico ensaio de 1958, intitulado "Dois conceitos de liberdade" (Berlin, 2002) - que tem por foco a não interferência, sobretudo por parte da autoridade política (mesmo se exercida de forma democrática), em direitos de propriedade ou "titularidades" (no sentido em que Nozick em- 
prega este termo) adquiridos por meio de uma cadeia de transações de mercado voluntárias e não fraudulentas. Dessa perspectiva, a justiça tem duas características distintivas: (1) é uma virtude da conduta individual (Hayek, 1976:31-33), não um atributo que possa ser imputado a uma ordem social e política, ou cuja ausência possa ser criticada em uma ordem social e política; e (2) é uma virtude que se exprime por meio de deveres negativos (Hayek, 1976:35-38), tais como "não interfira arbitrariamente na integridade física ou na propriedade de outros", "não descumpra suas promessas e contratos válidos", "não aja de forma desonesta ou fraudulenta", "não impeça uma pessoa de praticar sua religião ou de exprimir seu pensamento e suas opiniões" e assim por diante, e que se impõem como restrições não excepcionáveis às linhas de conduta que agentes individuais, privados e públicos, podem escolher. Nozick (1974:28-35) denomina essas injunções morais de "concepção side constraints" de direitos individuais. Mas o emprego da linguagem dos direitos, nesse caso, não deixa de ser dúbio, já que a ideia não é que certos direitos devem ser garantidos igualmente a todos, e sim que agentes privados e especialmente públicos estão sujeitos à exigência de se abster de adotar linhas de ação que, por mais socialmente desejáveis que possam ser, tenham o efeito colateral de violar "titularidades legítimas" (como são definidas pela própria teoria política libertariana). $\mathrm{O}$ foco não recai sobre a igualdade de direitos, quaisquer que sejam; a motivação central é o não descumprimento de deveres que incidem sobre a conduta individual ${ }^{2}$.

Observo, a esse respeito, que Sen comete o que me parece ser um equívoco de interpretação, ao afirmar que "todas as principais teorias éticas do ordenamento social têm em comum a aprovação da igualdade com base em alguma variável focal", e ao valer-se como exemplo, para sustentar isso, da teoria de Nozick: "um enfoque libertariano (como a teoria da titularidade desenvolvida de modo vigoroso em Anarchy, State, and Utopia, de Robert Nozick) pode conferir prioridade a amplas liberdades que devem ser garantidas igualmente a cada pessoa" (Sen, 1992:3) ${ }^{3}$. Não há essa ideia, no libertarianismo, de que "amplas liberdades" devem ser garantidas "igualmente" a todos. Essa é uma interpretação incorreta da teoria side-constraints de direitos individuais. De acordo com essa teoria, você está sob um dever não excepcionável de não violar os deveres morais que se aplicam à conduta individual (de agentes públicos ou privados); se e como amplas liberdades, mesmo aquelas restritas à garantia de um âmbito de liberdade negativa, serão 
garantidas a todos constitui outra questão, sobre a qual a teoria de Nozick (e o libertarianismo de modo geral) nada tem a dizer.

Disso se segue que nada além de um Estado comprometido com um estado de direito que converta em obrigações legais as restrições morais à ação que garantem a liberdade negativa tal como interpretada anteriormente, com ênfase na não violação de direitos amplos de propriedade, pode se justificar em nome da justiça. É possível que vastas desigualdades socioeconômicas se produzam em uma "sociedade livre". Mesmo sendo lamentável, isso não justifica que a autoridade política empregue a coerção coletiva da sociedade para realizar um padrão de justiça social. Se há desigualdades, isso não é produto das intenções ou dos planos de ninguém em particular, e sim de decisões tomadas de forma descentralizada por agentes individuais que decidem livremente - e são responsáveis pelas consequências das decisões que tomam o que fazer com os recursos sobre os quais têm titularidade plena, nisso se incluindo o exercício dos próprios talentos e capacidade produtiva. Ninguém, em particular, muito menos ainda, a sociedade, pode ser responsabilizado pelas desigualdades socioeconômicas que se geram na "ordem espontânea" produzida pelo mercado que Hayek batizou de "catalaxia" (Hayek, 1976:107-132)4. Esse é um dos sentidos - o de negar a responsabilidade pública - que pode ser atribuído à célebre frase de Margaret Thatcher de que "não há semelhante coisa como a sociedade". E, mais fundamentalmente, a tentativa de realizar um padrão de justiça distributiva na sociedade implica necessariamente a violação de deveres negativos não excepcionáveis, isto é, implica o emprego arbitrário e, portanto, injusto, do poder político.

A segunda vertente do liberalismo contemporâneo a ser considerada, quando o foco recai em concepções de justiça social e política, é aquela à qual se aplica a denominação liberalismo igualitário. John Rawls é a personalidade central dessa vertente, mas a ela também estão associados, com nuances importantes nas posições que defendem e em fronts diversos de debate, teóricos políticos como Brian Barry, Ronald Dworkin ${ }^{5}$, Norman Daniels, Thomas Nagel, Thomas Pogge, Joshua Cohen e Philippe Van Parijs. Para essa segunda vertente, não é suficiente, para que cada cidadão disponha das condições que lhe permitem viver sua vida de acordo com suas próprias convicções de valor moral, que seja institucionalmente garantida uma esfera de liberdade negativa; ademais, é preciso que os arranjos institucionais básicos da sociedade, políticos e socioeconômicos, propiciem a cada cidadão a ca- 
pacidade efetiva de fazê-lo. É essa noção de liberdade efetiva que distingue fundamentalmente o liberalismo igualitário do libertarianismo. Sobre os alicerces daquilo que pode ser denominado justiça liberal, em sentido mais restrito, para se referir aos direitos e liberdades que Benjamin Constant batizou de "liberdades dos modernos", deve se erguer, para o liberalismo igualitário, um edifício de justiça social. Para chegar à concepção de justiça que dá substância a essa noção de liberdade efetiva, há ao menos três ideias a salientar.

A primeira delas é a de que o objeto primário da justiça não é a conformidade da conduta de agentes individuais a deveres negativos de caráter absoluto, mas sim aquilo que Rawls, em Uma Teoria da Justiça, denominou "estrutura básica da sociedade". Esta noção, que não é de natureza normativa (mas que tem implicações normativas), abrange as principais instituições que distribuem ou que produzem a distribuição de direitos, oportunidades e recursos na sociedade, entre as quais se encontram: (1) as instituições que dizem respeito à distribuição de direitos e liberdades fundamentais; (2) as instituições que determinam a forma de acesso às posições de autoridade e poder (incluindo as oportunidades que o sistema político oferece para empresas e indivíduos ricos exercerem influência sobre as campanhas eleitorais); (3) as instituições, em particular o sistema educacional e o sistema de saúde, que determinam as oportunidades de acesso às posições ocupacionais mais valorizadas; e (4) o conjunto de instituições, abarcando as normas que regulam o direito de propriedade, o direito de herança e o sistema tributário e de transferências, que determinam a distribuição da renda e da riqueza na sociedade. O foco na distribuição de direitos, oportunidades e recursos - de "bens primários sociais", na linguagem de Rawls - e na estrutura básica da sociedade implica o reconhecimento, contrariamente à posição libertariana e à frase de Thatcher antes mencionada, de que a sociedade gera, sim, padrões persistentes de desigualdade e tem formas sistemáticas de distribuir as pessoas em hierarquias de poder, status e dinheiro. E se isso é assim, ainda que esses padrões de desigualdade não tenham resultado de atos individuais de injustiça nem tenham resultado de ações deliberadas de ninguém, em particular, há uma responsabilidade coletiva - que, em uma democracia política, recai sobre os cidadãos e seus representantes - de alterar as instituições de modo a tornar a estrutura básica mais justa. Mas o que seria, da ótica do liberalismo igualitário, uma sociedade justa?

Isso nos leva a uma segunda ideia fundamental, esta de natureza normativa. O ponto de partida da teoria política do liberalismo igualitário 
não é uma concepção de liberdade, e muito menos de liberdade negativa, e sim uma noção de igualdade. Uma sociedade justa é uma ordem social e política cujas instituições principais garantem a todos os cidadãos certa condição que podemos denominar igualdade humana fundamental ou igualdade moral. $O$ adjetivo moral, aqui, tem o sentido de explicitar que se trata de uma igualdade de status, e não exatamente de uma igualdade socioeconômica estrita do tipo que (podemos especular) os socialistas clássicos tinham em mente. A igualdade moral ou, para empregar o termo consagrado por Tocqueville, embora lhe conferindo uma conotação normativa mais positiva, a igualdade de condições é assegurada quando os arranjos institucionais básicos de uma sociedade - sua estrutura básica - devotam a seus cidadãos, independentemente de quanto dinheiro ou riqueza cada um possua ou de seus talentos e capacidade produtiva, um tratamento igual que só é possível àqueles que são portadores de direitos iguais. Em uma sociedade justa, a distribuição das vantagens e dos ônus da cooperação social se faz levando-se em conta e de modo a garantir esse status social e moral igual.

Essa é uma ideia normativa retirada da tradição democrática ocidental, ao menos quando não reduzimos suas aspirações normativas somente - não que isso seja pouco - à instituição de um governo democrático, mas também, e especialmente, quando as captamos mediante um ideal de sociedade de cidadãos livres e iguais. Esse ideal foi primeiramente formulado, de modo explícito, nas declarações de direitos do século XVIII, da Revolução Americana e da Revolução Francesa. De modo explícito, mas restrito a uma noção limitada do que antes denominei justiça liberal. Não se supunha, no século XVIII, que houvesse alguma incompatibilidade entre a linguagem moral dos direitos iguais e a escravidão e formas patentes de tratamento desigual entre homens e mulheres, no casamento, nas oportunidades educacionais e ocupacionais e nos direitos políticos. No entanto, parece razoável supor que o fundamento normativo que já se exprimia mesmo nessa concepção restrita de justiça liberal, a ideia de que todos os cidadãos merecem um tratamento e um respeito iguais, forneceu o combustível moral necessário para que um grande número de pessoas passasse a perceber essas desigualdades como formas intoleráveis de injustiça.

Estendida desse modo, a justiça liberal pode abarcar as liberdades dos modernos, direitos políticos iguais e uma noção de igualdade formal de oportunidades - no sentido de que ninguém seja institucionalmente impedido, por conta de atributos adscritícios (étnicos, raciais ou de gê- 
nero), de cultivar e exercer seus talentos, de escolher livremente sua ocupação e de disputar as posições mais valorizadas na sociedade. $\mathrm{O}$ liberalismo igualitário confere uma importância especial aos valores abrangidos por essa concepção de justiça liberal; isso se manifesta, em particular, na rejeição à posição de que a realização de outros objetivos socialmente desejáveis, como o desenvolvimento econômico ou a igualdade econômica, possa ser invocada como justificação para sacrificar aqueles valores. Mas a justiça liberal não é suficiente para substanciar a noção de liberdade efetiva mencionada anteriormente como o componente do liberalismo igualitário que mais fortemente o distingue do libertarianismo. Aqui é preciso introduzir uma concepção de justiça social ou de justiça distributiva. Uma forma de fazer isso consiste em mostrar a justiça social como uma extensão natural da justiça liberal (Nagel, 2003:64-65). Se estivermos preocupados com os direitos e liberdades civis e políticos fundamentais, que constituem o elemento central da noção de justiça liberal aqui empregada ${ }^{6}$, então deveremos também nos preocupar com oportunidades iguais de exercer esses direitos e liberdades. Um ponto a salientar a esse respeito é que tanto a concepção de justiça liberal como a de justiça social derivam de um fundamento normativo único, a ideia da igualdade humana fundamental. Mas como é possível extrair uma concepção específica de justiça distributiva dessa ideia genérica de igualdade moral?

Isso nos leva para a terceira ideia fundamental do liberalismo igualitário, também de natureza normativa. Trata-se do julgamento moral segundo o qual é injusto que as pessoas sofram as consequências distributivas de diferenças pelas quais não são responsáveis. Essas diferenças geram desigualdades socioeconômicas - de oportunidades sociais, de renda e riqueza - que deveriam ter seus efeitos tanto quanto possível mitigados pela estrutura básica de uma sociedade democrática justa. Em uma sociedade de cidadãos iguais, a distribuição de vantagens sociais pela estrutura básica da sociedade não pode ocorrer de acordo com fatores que são arbitrários de um ponto de vista moral. Denominemos esse argumento, formulado por Rawls em Uma Teoria da Justiça, "argumento da arbitrariedade moral". Isso diz respeito a fatores que se impõem às pessoas como contingências sociais - entendendo-se por isso posição e status social, riqueza e background cultural da família, a denominada "loteria social" - ou como contingências naturais - talentos e aptidões naturais que, em simbiose com a "loteria social", se converterão em capacidades produtivas desigualmente recompensadas (somente a título de ilustração, mencione-se que, nos Estados Unidos 
da primeira década dos anos 2000, a razão entre o rendimento médio dos presidentes de corporações, os chief executive officers, e o rendimento médio dos empregados chegou a níveis abissais de 531:1) ${ }^{7}$. A ideia é que há uma distinção de importância normativa capital, na reflexão sobre a concepção de justiça distributiva que é mais apropriada a uma sociedade democrática, entre aquilo que resulta de escolhas individuais genuínas - e, portanto, de empenho e mérito diferenciados, que podem ser considerados da ótica da responsabilidade individual - e contingências que deixam muitas pessoas em pior situação do que outras, sem que isso possa ser atribuído a escolhas conscienciosas das primeiras.

Essa distinção normativa fundamental está por trás da divisão profunda que se manifesta na discussão pública e acadêmica sobre a natureza da justiça distributiva nas sociedades liberal-democráticas de hoje. A divisão básica é a que existe entre os que identificam a justiça social com o combate a desigualdades moralmente arbitrárias que os arranjos institucionais básicos da sociedade podem e devem mitigar e aqueles que acreditam que o alcance da justiça é mais limitado, entre os quais se encontram os que supõem que uma sociedade liberal justa está isenta de responsabilidade por certas formas "naturais" de diferença (Nagel, 2003:80). Quem adota esta última posição, não o faz, necessariamente, com base em um ponto de vista libertariano puro, mas sim, muito frequentemente, com base em uma concepção meritocrática de justiça social segundo a qual a sociedade tem a responsabilidade de combater a pobreza severa e prover oportunidades que permitam às pessoas chegarem, por meio de seus próprios esforços, até onde seus próprios talentos e capacidades lhes possibilitem. As desigualdades de renda e riqueza resultantes, nesse caso, são atribuídas a mérito e a esforço individuais diferenciados, nisso se incluindo o esforço de cultivar os próprios talentos e elevar seu valor de mercado. Essa é certamente a ideologia mais poderosa de justificação de desigualdades socioeconômicas nas sociedades liberais do presente. É uma ideologia afirmada não somente pela direita política, mas que também impregnou a crítica feita por correntes políticas de centro-esquerda, como a Terceira Via da Grã-Bretanha dos anos Tony Blair, às ideias de responsabilidade e de justiça sociais depreciativamente rotuladas Old Labour.

A concepção de justiça social do liberalismo igualitário adota o primeiro dos dois pontos de vista que acabo de mencionar: no que diz respeito à justiça distributiva, o design da estrutura básica da sociedade deve 
ter por finalidade mitigar os efeitos de desigualdades arbitrárias de um ponto de vista moral para a distribuição de vantagens sociais e de oportunidades de vida. Isso abrange as desigualdades raciais e de gênero, as desigualdades de classe social - entendendo-se por isso, no presente contexto, sobretudo as desigualdades de riqueza, de posição social e as de background cultural e educacional das famílias nas quais a loteria social determina que as pessoas nasçam - e as desigualdades que resultam de recompensas diferenciadas aos portadores de talentos e capacidade produtiva diferenciados (um fator que resulta dos efeitos combinados e cumulativos da loteria genética e da loteria social). A ideia de que desigualdades arbitrárias, no sentido em que aqui se está entendendo, devem ser mitigadas leva à recomendação de dois princípios de justiça social. Um deles é um princípio de igualdade de oportunidades que cobra, pode-se dizer assim, as promessas não cumpridas da ideologia meritocrática das sociedades liberais. Para haver igualdade de oportunidades, não basta um princípio de "carreiras abertas ao talento", segundo o qual as posições ocupacionais mais valorizadas devem ser alocadas aos que são mais qualificados para exercê-las e que mais se empenham em desenvolver seus talentos e capacidade produtiva. Também é preciso que, em um momento suficientemente anterior no tempo - que provavelmente volta até as condições nutricionais e de saúde da mãe durante a gestação e ao acesso à educação infantil de qualidade $^{8}$ - todos tenham tido as mesmas oportunidades de adquirir as qualificações necessárias para competir em pé de igualdade pelo acesso às universidades de elite, a empregos de qualidade e às posições ocupacionais mais valorizadas. Isso requer, dos arranjos institucionais básicos e políticas públicas, a garantia de um mínimo social adequado (a abolição da pobreza), a garantia de oportunidades educacionais iguais (da educação infantil ao ensino médio) e o acesso igual à assistência médica de qualidade àqueles que têm uma condição similar de saúde 9 . Isso significa que, em uma sociedade de cidadãos iguais, a opção por escolas privadas e por seguros de saúde e hospitais privados caros seria equivalente à satisfação de outros gostos dispendiosos que alguns poucos podem se permitir, como o consumo de bens e a realização de viagens de férias de luxo, mas que não afeta o status social igual e a igualdade de tratamento garantidos a todos.

Mas mesmo que a pobreza fosse abolida e que esse princípio forte de igualdade de oportunidades fosse realizado em um grau muito maior do que é hoje nas sociedades liberais - no caso do Brasil, esse déficit é dramático: o que há é um sistema de apartheid educacional de fato, que 
vai da educação infantil de alta qualidade aos cursos mais competitivos das universidades de elite ${ }^{10}$-, isso não bastaria para realizar a justiça social. Ainda que uma meritocracia equitativa pudesse ser plenamente realizável - o que não é -, o mundo social que disso resultaria se pareceria mais com uma hierarquia social fundada no mérito diferenciado do que uma sociedade de cidadãos que têm um status social e moral igual. Essa é uma das razões pelas quais um princípio de igualdade de oportunidades deve ser complementado, da ótica do liberalismo igualitário, por um princípio de reciprocidade, ou de fraternidade, segundo o qual a distribuição de vantagens sociais - sobretudo de renda e riqueza - deve ser em grande medida dissociada de talentos e de capacidade produtiva diferenciados. Rawls exprimiu essa exigência por meio de seu "princípio de diferença", de acordo com o qual as desigualdades socioeconômicas só são justificáveis se forem estabelecidas para elevar no nível máximo possível as expectativas do "indivíduo representativo" que se encontra na posição mínima da sociedade.

Uma consequência de um princípio de justiça dessa natureza é que, mesmo que um mínimo social relativamente generoso seja garantido mediante benefícios em dinheiro (como o Programa Bolsa Família e as transferências indexadas ao salário mínimo, no caso brasileiro) e benefícios em espécie (na forma da provisão universal de serviços públicos de educação e saúde de qualidade), as desigualdades que estão acima desse mínimo devem ser reduzidas mediante tributação redistributiva da renda, da riqueza e de heranças e doações. Isso é necessário para fazer com que as desigualdades econômicas contribuam para elevar o quinhão de renda e riqueza daqueles que levaram a pior nas loterias social e genética, e, desse modo, fazer com que essas desigualdades contribuam para que os que se encontram na posição mais desprivilegiada também contem com os recursos necessários para viver de acordo com suas próprias convicções a respeito do que confere valor moral à vida. Sem essa exigência, a noção de liberdade efetiva do liberalismo igualitário seria moralmente vazia.

Essa interpretação do igualitarismo - que deve ser compreendida levando-se em conta os três componentes normativos discutidos: a justiça liberal, a igualdade equitativa de oportunidades e um princípio de reciprocidade que tem por objeto as desigualdades de renda e riqueza - contrasta não só com o liberalismo tradicional de Hayek e Nozick, mas também, como já foi mencionado, com a daqueles que acreditam que o alcance da justiça social está limitado à abolição da pobreza e à 
garantia de certo de padrão de vida decente para todos. Aqui, uma primeira área de controvérsia se apresenta, que não se limita ao contraste com a posição libertariana. Harry Frankfurt exprimiu vigorosamente esse ponto de vista não igualitário em um ensaio dos anos 1980, "Equality as a Moral Ideal". Segundo Frankfurt,

a igualdade econômica não se reveste, enquanto tal, de especial importância moral. Com respeito à distribuição de recursos econômicos, o que tem importância do ponto de vista da moralidade não é que todos tenham o mesmo, e sim que cada um tenha o suficiente. Se todos tivessem o suficiente, seria moralmente irrelevante caso alguns tivessem mais do que outros. Vou me referir a essa alternativa ao igualitarismoa saber, a de que aquilo que é moralmente importante em relação a dinheiro é que todos tenham o suficiente - como a "doutrina da suficiência" (Frankfurt, 1987:21-22).

Importa pouco, no momento, que o distribuendum adotado por Frankfurt seja o dinheiro ou a renda, já que essa é uma suposição simplificadora; o argumento não seria alterado caso a igualdade ou suficiência fossem definidas em alguma outra dimensão, como a do welfare ou do bem-estar interpretado de forma utilitarista, oportunidades, satisfação de necessidades ou capacidades no sentido de Amartya Sen. Mantendo-se essa suposição simplificadora, poderíamos definir suficiência com base, por exemplo, na definição de pobreza relativa empregada pela União Europeia, segundo a qual são pobres, em termos relativos, aquelas pessoas que têm uma renda inferior a 50 ou $60 \%$ da renda mediana de sua sociedade, isto é, aquele nível de rendimento que divide a população entre os $50 \%$ mais pobres e os $50 \%$ mais ricos. Pode-se considerar que esse é um padrão modesto de suficiência e que um padrão dessa natureza deve ser definido de alguma outra forma ${ }^{11}$. Não há dúvida de que a questão é relevante - talvez essa seja, afinal, a questão central que Amartya Sen está tentando responder em suas obras no campo da teoria da justiça (minha avaliação é que o enfoque de Sen da capacidade deve ser interpretado como um esforço teórico de formulação de um padrão de suficiência, e não como uma vertente de igualitarismo; substanciar esse ponto de vista, no entanto, exige uma argumentação que aqui não tenho como desenvolver). Mas o ponto a enfatizar no momento é outro: se, em dada sociedade, nenhuma pessoa tivesse renda abaixo de $60 \%$ da renda mediana e se, portanto, aceitando-se a suposição simplificadora que estou fazendo, certo padrão de suficiência fosse assegurado a todos, isso significaria que questões de 
desigualdade distributiva perderiam sua relevância moral? Diversamente daquilo que, valendo-se de um neologismo selvagem, pode ser denominado "suficientismo", os igualitários, de modo geral, entendem que vastas desigualdades de renda e riqueza que estão acima de um limiar de suficiência, como quer que seja definido, são moralmente objetáveis com base em um sentido de iniquidade comparativa. Da perspectiva do liberalismo igualitário, que propõe uma interpretação específica do igualitarismo, essas desigualdades constituem iniquidades, isto é, devem ser vistas como injustiça social, porque resultam não de escolhas individuais responsáveis e de mérito individual diferenciado, e sim de fatores que são arbitrários de um ponto de vista moral. Dessa ótica, mesmo que todos tivessem vidas suficientemente boas, desigualdades que deixassem alguns em situação pior do que outros, sem que isso pudesse ser imputado a escolhas responsáveis dos primeiros, ainda seriam moralmente objetáveis.

Como observa Brian Barry em seu último livro (Barry, 2005) ${ }^{12}$, a desigualdade tem efeitos que nada têm a ver com a pobreza, entre os quais a competição por "bens posicionais", que é tanto maior quanto maiores forem os níveis de desigualdade de renda e riqueza em uma sociedade (Barry, 2005:176-179). O que importa, nesse caso, não é quanto uma pessoa tem, em termos absolutos, e sim quanto ela tem em comparação a outros em sua sociedade. O que uma pessoa desprivilegiada é capaz de fazer com os recursos que tem, em sua sociedade, depende em parte dos recursos que outros, mais privilegiados, têm. Isso não diz respeito somente ao poder de compra de determinados bens - pensemos, por exemplo, na medida em que o acesso à moradia em condições apropriadas e em áreas urbanas que contam com infraestrutura adequada depende do poder relativo de compra - mas também a oportunidades educacionais e ocupacionais. Quando muitos têm uma formação educacional de nível superior, o acesso às posições mais disputadas dependerá de se ter frequentado uma universidade de elite. Além disso - continuo seguindo a análise de Barry -, os ricos podem assegurar melhores oportunidades ocupacionais a seus filhos, em comparação a outros com níveis similares de qualificação, por intermédio de seus contatos. Somente parte da transmissão de vantagens sociais de uma geração para outra se faz via educação e, quanto mais os estilos de vida daqueles que estão em estratos sociais diferentes discreparem, e essa discrepância será tanto maior quanto maiores forem os níveis de desigualdade, tanto mais exclusivos serão os contatos úteis. Por fim, os ricos têm como poupar seus filhos de certas escolhas condicionadas 
pela aversão ao risco que, no longo prazo, podem não se revelar as mais favoráveis. Os ricos, como enfatiza Barry, têm como possibilitar que seus filhos façam uso de capital que ninguém lhes emprestaria comercialmente, ou que assumam riscos financeiros que ninguém que seja prudente pode se dar ao luxo de assumir, quer para se arriscar em um negócio próprio, quer para se aventurar em uma carreira profissional que pode exigir custos pesados e recompensas pequenas, no curto prazo, mas trazer recompensas grandes (inclusive, mas não exclusivamente, financeiras) em um prazo mais longo. Em suma, quem se preocupa com oportunidades iguais deve também se preocupar com a desigualdade e com a equidade comparativa. O igualitarismo e o suficientismo muitas vezes coincidem nas recomendações que fazem, sobretudo quando há níveis elevados de pobreza na sociedade, mas é importante enfatizar que a igualdade - tal como aqui a estou interpretando e a realização de um padrão de suficiência são preocupações morais distintas.

Há duas outras considerações, independentes do argumento de mitigar os efeitos das loterias social e natural, que justificam a redução de desigualdades de renda e riqueza como um objetivo político distinto da abolição da pobreza e da garantia de um mínimo social decente. São duas considerações interligadas, que salientam os efeitos corrosivos que níveis elevados de desigualdade produzem sobre o apoio público à expansão do welfare state e a políticas redistributivas voltadas para beneficiar o quintil inferior da sociedade. Uma delas diz respeito àquilo que Ian Shapiro denomina "abismo de empatia" (Shapiro, 2003:133-135; 140-141) que se abre entre os estratos sociais superiores e os 20\% de baixo na distribuição de renda e riqueza. "Se o abismo entre você e os pobres que vê em volta é tão vasto a ponto de que nenhuma calamidade que você possa imaginar que se abata sobre você poderá colocá-lo nas circunstâncias deles, então desparecem quaisquer razões prudenciais que você possa ter para melhorar a sorte deles (idem:133)." Iniquidades relativas muito elevadas têm efeitos tóxicos sobre a solidariedade social.

O abismo de empatia anda junto, e essa é a segunda consideração, com os efeitos deletérios que níveis elevados de desigualdade econômica têm sobre o funcionamento dos sistemas políticos democráticos, ao possibilitarem que os ricos e super-ricos exerçam uma influência desproporcional - por meio de contribuições financeiras a campanhas eleitorais e de condições privilegiadas de acesso à comunicação políti- 
ca - sobre as deliberações políticas. Isso, por sua vez, torna mais difícil a adoção de reformas institucionais e de políticas de redistribuição de renda e riqueza e, de fato, tornam mais difícil a adoção e a sustentabilidade ao longo do tempo de políticas que objetivam melhorar as condições do quintil inferior da sociedade mesmo em termos absolutos. Essa é a razão pela qual Rawls sustenta que, se o que se quer é que a democracia política produza resultados justos, com respeito a questões de justiça básica, então é preciso garantir o "valor equitativo das liberdades políticas" (Rawls, 2008:277-280; Rawls, 2011:422-430). Níveis elevados de pobreza e desigualdade e uma excessiva concentração da riqueza e da propriedade degradam o valor que as liberdades políticas têm para os mais desprivilegiados e permitem que os mais favorecidos, porque são mais capazes de tirar proveito de direitos e oportunidades que em princípio são (em uma democracia política) iguais para todos, exerçam um peso desproporcional sobre os termos da discussão pública e sobre as decisões políticas ${ }^{13}$. Observe-se que, desse ponto de vista, é um dos elementos (as liberdades políticas) do que antes denominei justiça liberal que oferece a base normativa para justificar a redução da desigualdade econômica, nisso se incluindo o nível de desigualdade que até mesmo um princípio de justiça distributiva, como o princípio de diferença, considerado isoladamente, poderia autorizar.

Este é o momento apropriado para enfatizar um ponto nem sempre bem compreendido. O sentido do igualitarismo, da ótica do liberalismo igualitário, não pode ser reduzido a somente um de seus componentes normativos como, por exemplo, o princípio de diferença, que tem por objeto a distribuição de renda e riqueza na sociedade ${ }^{14}$. Embora isso certamente seja importante, não define o fim último da justiça social. Em uma passagem de Uma teoria da justiça em que se expressa claramente a ideia de liberdade efetiva que formulei aqui, Rawls afirma que, "considerando-se os dois princípios em conjunto, a estrutura básica deve ser organizada de forma a maximizar o valor para os menos favorecidos do sistema de liberdade igual compartilhado por todos. Isso é o que define o fim da justiça social" (Rawls, 2008: 251). Se as exigências combinadas dos três componentes normativos que examinei antes são realizadas pela estrutura básica da sociedade, o que se alcança não é simplesmente uma forma de igualdade distributiva, e sim, como afirmei no início, uma forma de igualdade de status que coloca os cidadãos em um pé de igualdade social e política. Rawls (2008:79; 91; 120-130) denominou "igualdade democrática" esse ideal de igualdade de status. ${ }^{15}$ Como observa Elizabeth Anderson (1999:312-314), 
aquilo a que os movimentos políticos igualitários historicamente se opuseram não foi tanto à distribuição em si mesma de bens materiais, e sim muito mais às relações sociais de desigualdade que geravam, e que se supunha que justificassem, desigualdades na distribuição de liberdades, oportunidades e recursos. Em consonância com esse espírito do igualitarismo, o ideal de igualdade democrática se opõe a hierarquias sociais fundadas em distinções raciais e de gênero, de berço e classe social e de talento e capacidade produtiva desiguais. E a forma de igualdade que os igualitários deveriam perseguir, de acordo com esse ideal, está centralmente relacionada a uma ordem social e política na qual direitos e liberdades fundamentais, oportunidades e recursos sociais escassos sejam distribuídos tendo em vista o propósito central de garantir um status social e moral igual aos cidadãos. Se essa forma de igualdade, que sem dúvida é mais elusiva do que uma noção de igualdade simples, como a igualdade de renda, for realizada, os cidadãos contarão com os recursos institucionais necessários para exercer a liberdade efetiva, tal como a interpretei antes, e para desenvolver no grau necessário as faculdades morais que os capacitam a serem membros plenamente cooperativos da sociedade ao longo da vida inteira: a faculdade de constituir e de revisar uma concepção do próprio bem e a faculdade de cooperar com outros com base em princípios de justiça (Rawls, 2011:57-64).

\section{IGUALITARISMO DE FORTUNA}

Passo, agora, a examinar uma linha de objeção à teoria da justiça distributiva do liberalismo igualitário que, diversamente da vertente de liberalismo tradicional que antes discuti, e diversamente da doutrina da suficiência, encontra-se dentro do próprio campo teórico do igualitarismo. É uma linha de objeção que pode ser formulada com base em teóricos como G. A. Cohen, Ronald Dworkin, Richard Arneson e John Roemer, que têm sido identificados, na literatura filosófica recente sobre justiça distributiva, como luck egalitarians. O que esses autores têm em comum é uma defesa do igualitarismo que interpreta de forma particularmente extremada o "argumento da arbitrariedade moral", de Rawls, a que antes fiz menção. À primeira vista, essa defesa poderia ser entendida como uma crítica à esquerda à ideia de igualdade democrática do liberalismo igualitário. Mas, como veremos, a contribuição específica dessa vertente à teoria da justiça distributiva encontra-se no esforço de abrir um espaço maior, em uma visão igualitária, à responsabilidade individual. Essa é uma temática importante, tanto na teoria 
da justiça como no debate político sobre o tipo de ação pública que se justifica para compensar desvantagens sociais. Espero conseguir mostrar as razões que há para rejeitar o tratamento normativo que o luck egalitarianism dá à responsabilidade individual e para preferir a forma como o liberalismo igualitário compatibiliza igualitarismo e responsabilidade pessoal. Esse é o tópico do qual me ocuparei no restante deste artigo.

Entre as críticas de Cohen às desigualdades excessivas que seriam autorizadas por um dos componentes do ideal de igualdade democrática, o princípio de diferença, está a de que, embora a condenação à arbitrariedade moral da fortuna social e da fortuna genética desempenhe um papel importante em sua justificação, esse princípio no melhor dos casos mitiga e não corrige os efeitos dessa arbitrariedade. A despeito dessa mitigação, é provável que, em uma sociedade que coloque em prática o princípio de diferença ou um princípio similar de justiça distributiva, aqueles que têm talentos e capacidades produtivas com maior valor de mercado acabarão entre os grupos em melhor situação, ao passo que aqueles que levam a pior nas loterias social e natural, acabarão entre os grupos menos privilegiados. O princípio de diferença não pode chegar a ser, como Rawls (2008:120-121) salienta, um "princípio de reparação" que objetive compensar as pessoas por todas as contingências sociais ou naturais que produzam desvantagens relativas. Contra isso, se poderia objetar que um princípio genuinamente igualitário exigiria uma compensação mais efetiva para quaisquer desigualdades que deixam uma pessoa em situação pior do que outra, sem que essas desigualdades possam ser justificadas por escolhas conscienciosas da primeira. Para Cohen (1989:916), a interpretação correta do igualitarismo é a de que o propósito da igualdade a ser realizada em uma sociedade justa é a eliminação de desvantagens involuntárias, isto é, desvantagens pelas quais aqueles que as sofrem não podem ser considerados responsáveis porque não refletem escolhas que os indivíduos tenham feito ou fariam ${ }^{16}$.

Os igualitários da fortuna - adotemos essa tradução para luck egalitarians - não estão de acordo sobre o que deve contar como "desvantagens involuntárias". Mas todos eles aceitam a distinção proposta por Ronald Dworkin (2000:73-78) entre dois tipos de sorte: a "sorte opcional" e a "sorte bruta". A sorte opcional é o resultado de um jogo no qual se entrou conscientemente ou de um risco conscientemente assumido. A sorte bruta é o resultado que se produz sem que o agente tenha feito 
nada para produzi-lo. Na visão de Dworkin, é justo que as pessoas sofram as consequências da sorte opcional, mas a sorte bruta é uma forma moralmente arbitrária de distribuir recursos. Algum detalhamento da argumentação complexa que Dworkin desenvolve para sustentar sua interpretação da igualdade distributiva em uma sociedade de cidadãos iguais, isto é, em uma sociedade na qual o Estado trata seus cidadãos com "uma consideração e um respeito iguais", se faz necessário. Dworkin contrasta dois equalisanda para a teoria da justiça distributiva: a "igualdade de bem-estar" (2000:11-64) e a "igualdade de recursos" (idem: 65-119). A igualdade de bem-estar (ou de welfare) é a posição normativa segundo a qual a igualdade distributiva só pode ser alguma função dos bem-estares subjetivamente definidos de indivíduos. Essa posição, a que Sen se refere como "welfarismo" (Sen, 1992:73-75 e 95-101; 1999:59-60), abarca, mas não se resume a interpretações da igualdade distributiva que estão no campo da ética utilitarista. Aqui vou me concentrar no equalisandum que Dworkin considera a expressão mais apropriada do princípio - que corresponde precisamente à noção de igualdade humana fundamental, a que me referi antes - de consideração e respeito iguais: a igualdade de recursos.

O problema essencial para chegar a uma concepção justificável de igualdade de recursos, de acordo com Dworkin, pode ser formulado da forma como se segue. Se os indivíduos fossem idênticos - em suas circunstâncias sociais e genéticas e em suas ambições e preferências então uma interpretação atraente da igualdade de recursos consistiria em dar a cada um uma parcela igual dos recursos externos da sociedade. Mas os indivíduos diferem em suas circunstâncias e também em suas ambições e preferências. As circunstâncias da pessoa podem ser consideradas parte de sua dotação de recursos, elas são os atributos do ambiente social ou genético que afetam sua capacidade de realizar seu plano de vida ou suas preferências e que, portanto, caem do lado da sorte bruta, ao passo que ambições e preferências caem do lado da sorte opcional. O ponto central da concepção de Dworkin é o de que uma concepção atraente de igualdade de recursos deve ter por objetivo igualar os complexos de recursos em seu conjunto - isto é, os complexos de recursos externos e internos - das pessoas. Mas muitos dos recursos circunstanciais não podem ser transferidos de uma pessoa para outra como, por exemplo, os pais, genes, deficiências de vários tipos, talentos e capacidade produtiva. A questão que se apresenta, então, é: que distribuição de recursos externos transferíveis pode-se supor que produza uma igualdade de complexos abrangentes de recursos? 
Dworkin enfrenta essa questão tendo por referência (é uma suposição simplificadora) uma economia de troca simples. Em uma economia desse tipo, há uma dotação agregada fixa de recursos e uma sociedade constituída por indivíduos que têm preferências distintas em relação a esses bens. Há três possibilidades que Dworkin considera, recorrendo à sua colorida parábola de imigrantes náufragos em uma ilha deserta que se dispõem a dividir igualmente os recursos externos da ilha. Dworkin supõe que eles aceitariam, como critério de divisão igual, o que ele denomina "teste da inveja": "nenhuma divisão de recursos é uma divisão igual se, uma vez que tivesse sido realizada, qualquer um dos imigrantes preferisse o complexo de recursos de alguma outra pessoa ao seu próprio" (Dworkin, 2000:67). A primeira possibilidade seria uma "divisão mecânica igual" que fosse realizada por um distribuidor escolhido para fazer a distribuiçãa ${ }^{17}$. O problema é que não há nenhuma "divisão mecânica de recursos" que possa satisfazer o teste da inveja (Dworkin, 2000:68). Qualquer combinação de recursos externos da ilha pela qual o distribuidor optasse, para compor cada um dos complexos de recursos, implicaria privilegiar certos gostos em detrimento de outros. Essa é uma forma de exprimir a ideia de que uma igualdade simples de resultados, ainda que fosse possível determinar de algum modo uma equivalência entre conjuntos heterogêneos de recursos externos, não é uma interpretação atraente do ideal de igualdade porque não tem como levar em conta as diferenças de ambições, preferências e planos de vida entre as pessoas.

Isso é levado em conta na segunda possibilidade considerada por Dworkin, que consiste em definir a igualdade de recursos como qualquer alocação (em equilíbrio) que fosse alcançada mediante um dispositivo de mercado, partindo-se de uma distribuição inicial igual de recursos. Dworkin descreve essa segunda possibilidade supondo que os imigrantes náufragos na ilha deserta dividiriam os recursos externos da ilha por meio de um leilão no qual cada um faria seus lances a partir de uma dotação inicial igual de conchas (Dworkin, 2000:66-71). O leilão hipotético é um dispositivo que tem por objetivo captar a ética da igualdade de recursos. A ideia central é que os recursos devotados à vida de cada pessoa devem ser iguais. Essa ideia central requer uma métrica - estamos falando, é claro, de uma métrica normativa. Para Dworkin, a métrica que leva em conta diferenças de ambições e preferências individuais é a do "custo de oportunidade" (Dworkin, 2000:149), daí porque o dispositivo contratualista (se podemos denominá-lo assim) do leilão hipotético é similar a um mercado. O leilão 
propõe que a única medida correta para avaliar o montante de recursos sociais escassos que são destinados à vida de uma pessoa consiste em perguntar quão importantes esses recursos são para outros. Esse custo de oportunidade deve figurar no senso que uma pessoa tem do que é ou do que deve ser legitimamente seu e no julgamento de cada pessoa sobre a vida que ela deveria levar. Se um dos hipotéticos imigrantes valoriza especialmente um pedaço de terra na praia, porque adora tomar banho de sol, então ele deve se dispor a pagar por esse recurso um preço que reflita o custo em que outros incorrem por terem de abrir mão do direito de empregar esse mesmo recurso para outras finalidades. ${ }^{18}$ Uma das críticas centrais de Dworkin à igualdade de bem-estar - à interpretação da igualdade segundo a qual o propósito central deveria ser o de igualar as pessoas tanto quanto possível no nível de bem-estar (de welfare) que alcançam pela satisfação de seus próprios gostos, preferências e ambições - é a de que não leva em conta custos de oportunidade dessa natureza. Se cultivo gostos caros como, por exemplo, gostos por vinhos e iguarias raros - estou pensando em um exemplo de Kenneth Arrow, que coloca em questão a possibilidade de realizar comparações interpessoais de bem-estar entre um indivíduo que satisfaz suas preferências gastronômicas com água e farinha de soja e outro que se sente profundamente infeliz sem vinhos e iguarias raros (Arrow, 1973:254) - não posso esperar subsídio da sociedade à satisfação desses gostos.

Se somente fosse preciso levar em conta diferenças de preferências, gostos e ambições, a teoria de Dworkin recomendaria parar por aqui. Arranjos de mercado que, no mundo real, cumprissem de forma aproximada o papel do leilão hipotético garantiriam a igualdade de recursos. Mas isso deixa fora da interpretação da igualdade distributiva diferenças que se devem à sorte bruta, como dotações distintas de recursos internos. A terceira possibilidade considerada por Dworkin envolve não somente um leilão ou um dispositivo de mercado para tratar das diferenças de preferências e ambições, mas também a ideia de um mercado hipotético de seguros concebido para levar em conta, em um primeiro momento, as deficiências físicas e mentais severas (os casos mais evidentes de má sorte bruta) e, em um segundo momento, os talentos e capacidade produtiva que têm baixo valor de mercado (Dworkin, 2000:73-99). Suponhamos que as partes do contrato social hipotético de Dworkin - os náufragos da ilha deserta - encontrem-se situadas em uma posição original na qual há um véu de ignorância fino: as partes conhecem suas preferências e planos de vida, mas não 
sabem se são portadoras de alguma deficiência nem que nível de renda serão capazes de auferir de seus talentos adequadamente desenvolvidos. Por trás desse véu de ignorância, cada um dos imigrantes poderia comprar recursos externos da ilha fazendo uso de seu quinhão inicial igual de conchas (de recursos), mas poderia também empregar uma parte disso para se segurar contra ter nascido com uma deficiência severa e contra a contingência de só ser capaz de obter, do exercício de seus talentos e capacidade produtiva, um nível baixo de renda. Haveria um equilíbrio, nessa economia de mercado em que existissem mercados para ocorrências contingentes, no qual as partes comprariam contratos de seguro que lhes prometessem compensação caso revelassem sofrer, no mundo real, de deficiências de diferentes tipos ou caso seus talentos só lhes permitissem obter um nível baixo de renda. Esse ponto de equilíbrio por trás do véu de ignorância é a referência segundo a qual avaliar a distribuição de recursos externos no mundo real, e conceber um sistema de tributação progressiva da renda e da riqueza e de transferências que assegura a igualdade de recursos (Roemer, 1996: cap. 7).

Como determinar esse ponto de equilíbrio ou, reformulando a questão, que nível de cobertura seria racional contratar, considerando-se que, quanto maior a cobertura contratada - no mundo real, quanto mais generosos forem as transferências e os benefícios do welfare state necessário para compensar os efeitos da sorte bruta -, tanto mais elevados terão de ser os prêmios (isto é, os impostos) a serem pagos? Um nível muito elevado de cobertura, o que equivale a uma pessoa ter direito de ser compensada por ser desprovida de talentos e capacidade produtiva que lhes propicie um nível de renda que está bem acima da média, escravizaria os mais talentosos. Sendo necessário colocar os prêmios em um nível muito elevado (isto é, dado que um nível muito elevado de tributação seria necessário para financiar um nível tão generoso de cobertura), os mais talentosos teriam de dar o máximo de sua capacidade produtiva para meramente pagar os prêmios a que estariam sujeitos. Partindo-se desse caso extremo, a racionalidade ex ante (sob o véu de ignorância) de escolha de um dispositivo hipotético de seguro contra não ter determinados talentos se tornaria mais forte conforme diminuísse o nível de cobertura contratado. Conforme esse nível cai, mais isso se aproxima do caso padrão de seguro (privado), em que as pessoas aceitam um pequeno custo financeiro certo para evitar uma perda que, por mais improvável que lhes pareça ser no presente, é grande o suficiente para motivá-las a arcar com o ônus do prêmio. 
Dworkin supõe que todos escolheriam, se pudessem, se segurar contra não ser capazes de ganhar aquilo que os colocaria no trigésimo centil da distribuição de renda, bastante acima do nível de renda adotado nos EUA e na Grã-Bretanha para que uma pessoa faça jus a transferências compensatórias. Garantindo-se a todos o direito de não cair abaixo desse limiar, ultrapassá-lo torna-se uma questão de sorte opcional, "pois quem quer que tenha as qualificações necessárias para obter um ganho que se encontra, digamos, no nível do trigésimo centil também terá os talentos para obter um ganho em um nível mais elevado, e por isso preservará uma considerável liberdade de escolha com respeito ao tipo de trabalho [que prefere], e com respeito à combinação que prefere entre trabalho, e esforço despendido na atividade de trabalho, e consumo adicional" (Dworkin, 2000:98).

Iniciei essa discussão afirmando que, à primeira vista, o igualitarismo de fortuna poderia se apresentar como uma crítica à esquerda ao ideal de igualdade democrática do liberalismo igualitário, já que, ao passo que este ideal propõe somente mitigar os efeitos de contingências sociais e naturais, o sentido do igualitarismo se exprimiria de forma mais clara na exigência de que as desvantagens relativas devidas à sorte bruta sejam eliminadas. Mas examinando-se bem as coisas, grande parte do apelo do igualitarismo de fortuna vem não propriamente de seu impulso igualitário, e sim do lugar mais proeminente, em comparação ao liberalismo igualitário, reservado à escolha e à responsabilidade individuais. John Roemer (1996: cap. 7) e Will Kymlicka (1990:71-85) veem nisso a marca da contribuição do igualitarismo de fortuna - de Dworkin, em particular - à teoria da justiça distributiva. $\mathrm{O}$ lugar mais proeminente à responsabilidade individual se manifesta já na formulação de princípios fundamentais de justiça social. Ao formular seu princípio de igualdade de recursos, e combinando a segunda e a terceira possibilidades que foram examinadas antes, Dworkin afirma que

por um lado, devemos, sob pena de violar a igualdade, permitir que a distribuição de recursos em qualquer momento dado seja (como podemos dizer) sensível à ambição. Ou seja, essa distribuição deve refletir o custo ou o benefício para outros das escolhas que as pessoas fazem de tal forma que, por exemplo, aqueles que escolhem investir ao invés de consumir, ou consumir de forma mais modesta ao invés de mais cara, ou trabalhar de formas mais úteis ao invés de menos úteis, devem poder reter os ganhos que se produzem dessas decisões em um leilão 
igual seguido de livre comércio. Mas, por outro lado, não devemos permitir que a distribuição de recursos seja, em qualquer momento dado, sensível a dotações [endowment sensitive], isto é, afetada por diferenças de capacidade do tipo que produzem diferenças de renda, em uma economia de laissez-faire, entre indivíduos com as mesmas ambições (Dworkin, 2000:89).

Embora nem todos os teóricos luck egalitarians, como Richard Arneson $(1990 ; 1991)$ e G. A. Cohen, estejam de acordo com a noção de Dworkin de igualdade de recursos, todos eles aceitam a justiça de quaisquer desigualdades que resultam de escolhas conscienciosas de pessoas adultas. E, como já foi mencionado, todos eles aceitam e colocam grande ênfase na distinção de Dworkin entre resultados pelos quais os indivíduos são responsáveis - que resultam de suas escolhas voluntárias e que, portanto, estão sob a égide da sorte opcional - e resultados ou desvantagens relativas pelos quais não são responsáveis - e que, portanto, estão sob a égide da sorte bruta. Mas essa ênfase na escolha e na responsabilidade individuais, longe de levar a uma interpretação mais plausível do propósito do igualitarismo, representa uma vasta concessão à crítica conservadora mencionada no início deste artigo, que justamente sustenta que o igualitarismo corrói a responsabilidade individual ao tirar recursos daqueles que são "merecedores" e ao garantir benefícios e resultados independentemente de empenho e de escolhas pessoais.

Permitam-me abrir um parêntese nesse ponto da discussão. O princípio da responsabilidade individual encontra-se por trás da justificação dos níveis crescentes de desigualdade de renda e riqueza que se verificam em muitos países do mundo, de forma mais acentuada nos países desenvolvidos anglo-saxônicos, mas também em países do sul da Europa, na Índia e na China. Mas há dois pesos e duas medidas quando se trata de apelar à responsabilidade individual no debate público de questões que têm relevância para a justiça social.

Inicio o parêntese com algumas breves observações sobre esse aumento da desigualdade. Um estudo recente dos economistas Anthony Atkinson, Thomas Piketty e Emmanuel Saez mostra que a parcela da renda total que, nos Estados Unidos, vai para os $1 \%$ mais ricos (aqueles que, em 2007, tinham uma renda anual acima de 400 mil dólares), passou de $9 \%$ em 1970 para 23,5\% em 2007, o que corresponde ao nível mais elevado de desigualdade de renda desde 1928 (Atkinson, Piketty e Saez, 2011) ${ }^{19}$. Para cada dólar de crescimento real da renda entre 1976 
e 2007, 58 centavos foram para os $1 \%$ mais ricos. Na maior parte desses países, uma parcela significativa dos ganhos obtidos pelos $1 \%$ mais ricos se deveu a um forte crescimento dos rendimentos de trabalho mais elevados (em comparação aos rendimentos de capital), especialmente os salários e gratificações dos executivos de nível mais alto. A desigualdade também aumentou de forma acentuada entre os que se encontram no 90 o centil e os que se encontram no 50 o centil da distribuição de ganhos salariais. Os ganhos dos assalariados que se encontram no $90^{\circ}$ centil, tais como os que desempenham funções gerenciais, cresceram muito mais rapidamente do que os salários dos trabalhadores, tais como operários e assistentes administrativos, que se encontram no 50 o centil (Rajan, 2010). Invertendo tendências à redução da desigualdade de renda que se verificavam, em países como os Estados Unidos e a Grã-Bretanha, desde a Segunda Guerra Mundial, a partir da década de 1980, a distribuição de renda se tornou mais desigual, e os ricos, especialmente os que se beneficiam dos supersalários (incluindo os bônus) do setor financeiro, tornaram-se e continuam se tornando cada vez mais ricos. Não há uma causa única para essa inversão. Certamente as reduções de impostos para os mais ricos nos anos 1980, nos Estados Unidos e na Grã-Bretanha sob os governos (respectivamente) Reagan e Thatcher, e que foram mantidas por todos os governos subsequentes, contribuíram para isso. Também há fatores que respondem pelo crescimento da desigualdade de renda pré-tributação. No caso de uma economia capitalista desenvolvida como a dos Estados Unidos, as mudanças tecnológicas requerem e recompensam de forma crescentemente diferenciada a força de trabalho de alta qualificação educacional e profissional; no entanto, as oportunidades educacionais permanecem muito desiguais. Como Rajan (2010) observa, isso é especialmente importante para explicar o aumento do diferencial, mencionado anteriormente, entre aqueles que obtêm rendimentos que os colocam no $90^{\circ}$ centil e aqueles, os que estão na posição do trabalhador mediano, que obtêm rendimentos que os colocam no $50^{\circ}$ centil. Não tenho como examinar de forma apropriada a questão, que envolve uma discussão empírica complexa, mas cabe pelo menos mencionar uma mudança de cunho ideológico que tem conexão com a temática que estou discutindo.

Já foi dito que a ideologia do mérito e do esforço individuais presta-se a justificar as desigualdades que beneficiam especialmente os ricos e os super-ricos. Entretanto, no capitalismo dos anos 1980 em diante, essa justificação dissociou-se inteiramente da velha ideologia calvinista, 
que se fundava em uma ética do esforço e da responsabilidade individuais, mas que tinha por componentes, no que diz respeito à conduta dos mais privilegiados, certo sentido de noblesse oblige, o cultivo da confiança e da boa-fé nas relações econômicas e um compromisso com a criação de valor econômico no longo prazo. O novo herói do capitalismo, como se evidenciou de forma dramática na crise financeira de 2008, que resultou na chamada Grande Recessão da qual o mundo desenvolvido (no momento em que escrevo, no segundo semestre de 2011) ainda está longe de ter se recuperado, já não tem peias morais de espécie alguma. Quaisquer práticas, mesmo aquelas que envolvem as condutas de risco excessivo exemplificadas pela produção de inovações financeiras, como derivativos lastreados em hipotecas subprime, e que foram protagonizadas por grandes instituições financeiras de países capitalistas desenvolvidos, com as bênçãos das agências de avaliação de risco de alto prestígio nos denominados mercados, são permissíveis, se tiverem por objetivo maximizar o valor das ações, a rentabilidade imediata e as stock options dos executivos. E, como foi o caso até o momento, nenhum executivo de alto nível das instituições financeiras envolvidas foi pessoalmente responsabilizado pelas consequências desastrosas, para as vidas de milhões de pessoas, de tais práticas inovadoras. Não parece absurdo especular que, entre as causas da Grande Recessão, encontrem-se não somente as falhas de regulamentação financeira e a própria desigualdade de renda entre ricos e super-ricos, por um lado, e o restante da sociedade ${ }^{20}$, por outro, mas também um fenômeno mais profundo e de consequências imprevisíveis: um colapso moral do capitalismo ${ }^{21}$. Tocqueville observou, há mais de 150 anos, em O Antigo Regime e a Revolução, que privilégios dissociados de um sentido de noblesse oblige geram um senso de indignação entre os estratos da sociedade excluídos desses privilégios que pode servir de combustível para ideias de mudança radical (Tocqueville, 2009 [1856]: Livro II, cap. 1). De fato, vimos um senso de indignação e de mal-estar no capitalismo ganhar uma face pública no Movimento dos Indignados que se iniciou nos acampamentos de protesto contra o desemprego e o sistema econômico em Madri, em maio de 2011, adquiriu novo impulso com o movimento Occupy Wall Street, em Nova York em setembro de 2011, e que daí - sob o slogan "We are the 99\%" - se alastrou em manifestações contra a desigualdade econômica e o poder das finanças que ocorreram em mais de 80 países do mundo. Mas constitui outra questão saber se forças políticas de esquerda serão capazes de traduzir isso em uma visão coerente e praticável de justiça social. 
Não me arriscarei a fazer previsões sobre os efeitos de longo prazo da crise de 2008. O ponto que quero ressaltar com este parêntese é mais limitado. Altos executivos de grandes corporações e bancos raramente são responsabilizados pelas práticas temerárias e condutas de risco que não têm outro propósito que não o de maximizar no curto prazo a bottom line de suas companhias. Quando tudo dá errado, como em 2008, ou quando desmoronou, nos países do Atlântico Norte, a gigantesca pirâmide de Ponzo montada com base em produtos financeiros inovadores lastreados em "hipotecas podres", os novos heróis do capitalismo ainda podem recorrer ao argumento do too big to fail para justificar que gigantescos mecanismos de socialização das perdas sejam colocados em prática pelos Estados e para que, dessa forma, escapem de enfrentar as consequências de suas condutas. De outra parte, como ressalta Brian Barry (2005:142-153), e nesse ponto fica claro por que falar em duplo padrão, o princípio da responsabilidade individual recai com extrema dureza, nos Estados Unidos e na Grã-Bretanha, sobre os que fraudam os "testes de meios" (ao não declarar pequenas rendas que obtêm na economia informal) e os "testes de trabalho" para obter benefícios de assistência social. De modo mais geral, reformas dos sistemas de bem-estar social foram realizadas nos dois lados do Atlântico, e sob os governos de centro-esquerda de Clinton e Blair, com base na ideia de que os benefícios em dinheiro de assistência social não constituem direitos, justificados por exigências de justiça, e devem ter por contrapartida a responsabilidade pessoal dos beneficiários. No caso dos Estados Unidos, entre as condicionalidades do programa Temporary Assistance For Needy Families, que foi criado em 1997 para substituir o programa Aid to Families With Dependent Children (um dos componentes centrais do New Deal de Roosevelt), está a de que mães de crianças pequenas, em famílias uniparentais pobres, disponham-se a realizar pelo menos 30 horas semanais de "atividades de trabalho". De desempregados e mães solteiras pobres espera-se, para que façam jus a modestas transferências monetárias, que assumam a responsabilidade pela sua situação e se empenhem em encontrar formas de sustentarem a si próprios. Esses são os pobres "responsáveis" e, por isso, merecedores de apoio público.

A análise precedente ressalta o quanto há de hipocrisia em se exigir responsabilidade pessoal de mães solteiras pobres, pessoas doentes, desempregados e outros beneficiários de programas de assistência social, e mesmo dos chamados welfare cheats, quando os super-ricos do setor financeiro e de grandes corporações, ademais de contarem com 
uma ideologia que justifica suas remunerações extraordinariamente elevadas com base no mérito individual, podem tomar suas decisões e fazer suas escolhas, ao que parece, em uma zona moralmente livre. Fecho o parêntese dizendo que isso deveria servir de alerta contra os esforços teóricos para levar em conta um princípio de responsabilidade individual já no nível da formulação de princípios fundamentais de justiça. Voltemos à discussão do igualitarismo de fortuna. Não estou afirmando que Dworkin e outros luck egalitarians endossariam um tratamento à responsabilidade pessoal tão mesquinho quanto o que acabo de examinar, no caso dos beneficiários de programas de assistência social nos Estados Unidos e na Grã-Bretanha. Mas há um componente desse tratamento que contamina a teoria da igualdade distributiva do igualitarismo de fortuna: a distinção entre os desprivilegiados merecedores e os não merecedores, entre os que são ou não responsáveis por sua má fortuna.

Recordemos o que foi dito antes sobre a distinção central de Dworkin. Para as desvantagens que se devem à má sorte opcional, aquelas que resultam de gostos e preferências que a pessoa escolheu cultivar ou de riscos nos quais a pessoa escolheu incorrer, nenhuma compensação é devida por parte da sociedade. Para esses casos, como vimos, aplica-se a métrica dos custos de oportunidade, que só pode ser realizada por arranjos de mercado e que obriga a pessoa a assumir a responsabilidade pelas consequências desfavoráveis de suas próprias preferências, ambições e escolhas. Para as desvantagens que se devem à má sorte bruta, aplica-se a métrica normativa do seguro hipotético, que justifica as compensações e benefícios de um welfare state. Mas, como Elizabeth Anderson (1999) sustentou em importante ensaio de crítica ao igualitarismo de fortuna, há problemas no tratamento dispensado tanto às vítimas da má sorte opcional como às vítimas da má sorte bruta. Há vítimas da má sorte opcional que uma interpretação plausível do igualitarismo não pode admitir que fiquem ao relento, isto é, que arquem inteiramente com as consequências de suas escolhas. Para exemplificar, pensemos nos casos de pessoas que desenvolvem hábitos alimentares que podem lhes causar sérios problemas de saúde, ou de pessoas que praticam esportes que podem resultar em acidentes que causam deficiências graves ou ainda, para mencionar um dos exemplos de Anderson, no de pessoas em situação de vulnerabilidade (normalmente mulheres) que cuidam de outros, de filhos, de pessoas doentes ou de idosos. Estaríamos justificados em supor, nesses casos e em outros semelhantes, que a sociedade oferecer compensação a essas pessoas pelas 
desvantagens que sofrem seria moralmente equivalente a subsidiar gostos caros? Por outro lado, as razões oferecidas para compensar as desvantagens devidas à má sorte bruta estigmatizam os beneficiários. Em uma sociedade na qual o igualitarismo de fortuna fosse adotado como concepção pública de igualdade distributiva, seria publicamente reconhecido que as pessoas que merecem compensação pelas desvantagens que sofrem, têm direito a isso não em virtude de seu status moral e social igual, e sim em virtude de sua dotação inferior de recursos internos - seja porque são portadoras de deficiência e de necessidades especiais, seja porque seus talentos e capacidade produtiva têm pouco valor de mercado. Aqueles que pleiteariam compensação em nome da justiça o fariam com base em uma dotação de recursos internos considerada inferior à de outros na sociedade. Será essa base pública de justificação à compensação de desvantagens compatível com o princípio de consideração e respeito iguais pelos cidadãos, que Dworkin considera a "virtude soberana" de uma sociedade justa?

Extremar o argumento da arbitrariedade moral, com o propósito de abrir espaço para a responsabilidade pessoal na formulação de princípios fundamentais de justiça, acaba por solapar o ideal de igualdade democrática, tal como interpretado pelo liberalismo igualitário. O que esse ideal propõe é que as desvantagens a serem compensadas e as necessidades a serem satisfeitas, como quer que tenham se produzido, se pela sorte opcional ou pela sorte bruta, são aquelas que têm relação com as capacidades dos cidadãos que são definidoras de sua condição de pessoas morais livres e iguais - a faculdade moral de constituir uma concepção do próprio bem e a faculdade moral de um senso de justiça. A suposição é que uma noção de igualdade de bens primários, interpretada de forma apropriada, pode dar conta das necessidades dos cidadãos assim entendidas ${ }^{22}$. Essa suposição abre outra frente de discussão, dessa vez com o enfoque da capacidade que vem sendo desenvolvido por Amartya Sen. Um dos mantras de Sen é a proposição segundo a qual diferenças de dotação natural e de situações sociais implicam capacidades diferenciadas de converter recursos distribuídos por instituições (tais como os bens primários sociais) em diferentes combinações de functionings valiosas ou em diferentes "conjuntos capacitários". Tratei desse debate em outro artigo (Vita 1999). Valeria a pena reexaminá-lo, não somente porque é preciso levar em conta uma contribuição recente de peso de Sen (2009) à teoria da justiça, mas também para avaliar em que medida uma crítica similar àquela que aqui desenvolvi ao tratamento que o igualitarismo de fortuna dá à má sorte bruta, espe- 
cialmente às diferenças naturais, não se aplicaria também ao enfoque da capacidade. Mas isso terá de ficar para outro momento.

\section{LIBERALISMO IGUALITÁRIO E RESPONSABILIDADE PESSOAL}

O que levou o igualitarismo de fortuna a se equivocar - como sustentei que é o caso - na interpretação das aspirações normativas do igualitarismo? Argumentei que isso se deve à tentativa de incorporar um princípio de responsabilidade pessoal já no nível da formulação de um princípio fundamental de justiça distributiva. E as recomendações que se seguem disso, quer esse princípio seja interpretado como a "igualdade de recursos" proposta por Dworkin, quer seja interpretado como "igualdade de acesso à vantagem" proposta por G. A. Cohen, têm a implicação de que o Estado - os cidadãos considerados como um corpo coletivo - deverá fundamentar a compensação de desvantagens sociais em juízos moralizantes sobre preferências, ambições e escolhas individuais, e sobre dotações naturais e capacidades produtivas tidas como inferiores.

Finalizo este artigo tratando da seguinte questão: se a interpretação do igualitarismo de fortuna tem essa implicação problemática, que lugar, afinal, o liberalismo igualitário reserva à responsabilidade individual em sua própria interpretação do igualitarismo?

Para responder a essa questão, examinarei uma incoerência que G. A. Cohen afirma ter encontrado na teoria de Rawls, que diz respeito justamente a esse tópico ${ }^{23}$. O problema, que, como nota Cohen, apresenta-se ao pensamento igualitário de esquerda de modo geral, é o de "reconciliar a representação do indivíduo como capaz de dirigir responsavelmente a formação de seus próprios gostos com as suposições de que Rawls se vale em outros momentos para justificar seu igualitarismo" (Cohen, 1993:13-14; Cohen, 1989:912-916). De um lado, estão as suposições necessárias à justificação do igualitarismo. Rawls rejeita a ideia de que a distribuição desigual de oportunidades e recursos escassos possa se justificar pelo mérito individual. $\mathrm{O}$ argumento é que o mérito individual - um atributo que é indissociável das preferências, gostos e ambições de uma pessoa como, por exemplo, as atitudes individuais que valorizam o trabalho e o esforço persistente em detrimento do lazer, a poupança em detrimento do consumo imediato, a disposição de assumir riscos, e assim por diante - é fortemente condicionado por fa- 
tores moralmente arbitrários. Vejamos o que diz Rawls na seção 48 de Uma teoria da justiça:

As parcelas distributivas (...) não estão correlacionadas com o valor moral, uma vez que a distribuição inicial dos talentos naturais e as contingências do seu cultivo e desenvolvimento nos primeiros anos de vida são arbitrárias de um ponto de vista moral. O preceito que intuitivamente parece chegar mais próximo de recompensar o mérito moral é o da distribuição segundo o esforço, ou melhor, segundo o esforço consciencioso. Mais uma vez, porém, parece claro que o esforço que uma pessoa está disposta a fazer sofre influência de suas capacidades e talentos naturais e das alternativas que estão ao seu alcance. Outros fatores permanecendo constantes, é mais provável que os mais talentosos se esforcem conscientemente, e parece não haver um modo de não levar em conta sua maior boa fortuna. A ideia de recompensar o mérito é impraticável (Rawls, 2008:387-388) ${ }^{24}$.

De outro lado, acompanhando o raciocínio de Cohen, está a suposição de que o indivíduo deve ser responsável pelo cultivo de seus próprios gostos, preferências e fins. Rawls apela a essa suposição para explicar por que sua concepção de igualdade distributiva não necessita preocupar-se com a satisfação de gostos caros que, como mencionei brevemente antes, é um problema para as concepções, entre as quais concepções utilitaristas de igualdade, que concebem a igualdade distributiva como uma função de utilidades ou de bem-estares subjetivamente definidos. Permitam-me citar a passagem completa de Rawls (também citada por Cohen) que é pertinente ao ponto em questão:

Como pessoas morais, os cidadãos têm parte da responsabilidade na formação e no cultivo de seus próprios fins últimos e preferências. Não se pode considerar uma objeção ao emprego dos bens primários o fato de que isso não acomoda aqueles que têm gostos caros. É preciso argumentar, ademais, que é desarrazoado, senão mesmo injusto, supor que tais pessoas são responsáveis por suas preferências e exigir que elas se virem o melhor que podem. Mas sustentar esse argumento parece pressupor que as preferências dos cidadãos estão fora de seu próprio controle, como se fossem inclinações e anseios que simplesmente sobrevêm. A impressão que se tem, nesse caso, é que se veem os cidadãos como portadores passivos de desejos. O emprego dos bens primários, entretanto, apoia-se na capacidade que temos de assumir a responsabilidade por nossos próprios fins (Rawls, 1982:168-169). 
Cohen acha que as duas partes da teoria de Rawls não se encaixam. As preferências individuais são vistas de uma forma, quando se trata de desqualificar o mérito como um princípio distributivo para a estrutura básica da sociedade, e de outra, quando o que está em questão é justificar a não satisfação de gostos caros. O liberalismo igualitário rawlsiano e, Cohen supõe, o pensamento igualitário de modo geral parecem se defrontar com a desconfortável impossibilidade de conciliar as suposições que fundamentam um princípio de igualdade distributiva com as suposições que fundamentam um princípio de responsabilidade pessoal. Na leitura luck egalitarian que Cohen faz da solução para esse problema, se poderia supor que a justificação de compensação por desvantagens estaria sempre na dependência de juízos sobre se essas desvantagens podem ser atribuídas à sorte bruta - e, portanto, a circunstâncias que estão fora do alcance de escolhas individuais autônomas ou à sorte opcional - e, portanto, são desvantagens pelas quais os indivíduos podem ser responsabilizados. "De acordo com minha interpretação", diz Cohen, "o igualitarismo não prescreve a correção ou a compensação da desvantagem enquanto tal. Essa interpretação tem por alvo, mais precisamente, a desvantagem 'involuntária', que é aquela que não reflete a escolha do agente. (...) Ao avaliar se a justiça (em contraste com a caridade) requer ou não redistribuição, o igualitário pergunta se alguém que sofre de uma desvantagem poderia tê-la evitado ou se agora tem como evitá-la. Se poderia tê-la evitado, não tem nenhuma pretensão à compensação, de um ponto de vista igualitário" (Cohen, 1989:920). Estamos de volta à distinção problemática, que está no coração do igualitarismo de fortuna, entre os que são merecedores e os que não são merecedores de compensação por parte da sociedade.

Há, entretanto, um sério mal-entendido na objeção de Cohen a Rawls. Julgamentos sobre preferências, ambições e escolhas individuais, e sobre a responsabilidade pessoal, não desempenham nenhum papel na justificação dos princípios de justiça do liberalismo igualitário e não desempenham nenhum papel nas comparações interpessoais de bemestar baseadas no índice de bens primários. Essas comparações não envolvem nenhum juízo sobre preferências e escolhas individuais nem sobre o que as pessoas merecem individualmente, tendo em vista a distinção entre escolha e circunstância, ou entre sorte opcional e sorte bruta. O objeto da justiça é a estrutura básica da sociedade e não o de constituir juízos moralizantes sobre atitudes e escolhas individuais imprudentes ou autocentradas, nem a reparação de supostas injustiças da natureza em casos individuais - e observe-se que, em outros de seus es- 
critos (Cohen, 1992; e, especialmente, Cohen, 199725), Cohen investe justamente contra essa ideia central do liberalismo igualitário de que o foco da justiça deve se restringir à estrutura básica, não alcançando condutas, atitudes e escolhas individuais. A suposição é a de que há direitos e liberdades, oportunidades e recursos que as pessoas, mesmo divergindo em seus valores e atitudes individuais, têm razões para valorizar. A suposição seguinte é a de que as instituições básicas da sociedade devem ser moldadas de forma a assegurar que o acesso a uma parcela equitativa desses bens e oportunidades permita a cada cidadão exercer a liberdade efetiva, do modo como essa ideia foi interpretada antes, e desenvolver e preservar as capacidades morais que lhe possibilitem ser um membro cooperativo da sociedade ao longo da vida inteira. O que cada um fará com os recursos institucionais que lhes foram propiciados - que preferências e gostos cultivará, que fins tentará realizar - já não será, via de regra, um assunto da sociedade. Se a forma de igualdade distributiva prescrita pelo ideal de igualdade democrática for realizada pelas instituições básicas da sociedade, posições relativas desiguais (diferenças de renda, por exemplo) poderão resultar de preferências e escolhas individuais distintas, que é o âmbito apropriado para a manifestação da responsabilidade pessoal em uma visão igualitária. Mas a responsabilidade pessoal não desempenha nenhum papel na justificação do próprio ideal de igualdade democrática e na justificação das recomendações institucionais que objetivem realizar esse ideal.

A conclusão a que chegamos está muito longe de confirmar a contradição apontada por G. A. Cohen. Somente a garantia da igualdade distributiva na estrutura básica da sociedade torna possível evitar juízos públicos sobre o mérito intrínseco de preferências e escolhas individuais, ou sobre a inferioridade de determinadas desvantagens individuais que se devem à má sorte bruta, e oferecer um tratamento normativamente apropriado para a responsabilidade pessoal em uma visão liberal-igualitária.

(Recebido para publicação em setembro de 2011)

(Versão reapresentada em dezembro de 2011) 


\section{NOTAS}

1. Uma versão "clássica" (não tanto por seus méritos intelectuais, e sim muito mais pela influência que exerceu no debate público estadunidense) dessa crítica, que é voltada a qualquer tipo de ação compensatória por parte do Estado, é a de Charles Murray em Losing Ground. Murray (1994[1984]) sustentou que os benefícios do welfare state destroem o caráter e encorajam as mulheres pobres a terem filhos para obter benefícios maiores de assistência social.

2. Também para Hayek (1976: cap. 8), normas de justiça são normas de proibição da conduta injusta que se aplicam à conduta individual. Entendo que a concepção que Nozick denomina side-constraints de direitos individuais também vale para a interpretação de Hayek da justiça e da linguagem dos direitos individuais. Não tenho como me estender nesse ponto no momento, mas observo que nenhuma perspectiva normativa que interprete as normas de justiça como deveres negativos que se aplicam à conduta individual pode se comprometer, a não ser em um sentido puramente formal, com uma ideia de direitos iguais para todos, nisso se incluindo direitos a liberdades fundamentais.

3. Destaques no original. A não ser que uma edição brasileira seja empregada, todas as traduções de passagens extraídas de obras escritas em inglês (ou traduzidas para o inglês) são minhas.

4. Para Hayek, "ordens cataláticas" se opõem a "ordens teleocráticas". Uma "ordem teleocrática" é dirigida para um fim específico, ao passo que uma "ordem catalática", que para Hayek corresponde àquela de uma sociedade liberal livre, é uma ordem espontânea, que emerge da busca, por indivíduos e grupos, de fins e objetivos distintos. Normas de justiça, em uma "ordem catalática", estão confinadas a normas "que são quase sempre negativas no sentido de que proíbem, e não prescrevem determinados tipos de ações" (Hayek 1976: 36); e são normas que "não conferem direitos a pessoas específicas, mas estabelecem as condições sob as quais esses direitos podem ser adquiridos" (ibid., 38).

5. Embora Dworkin certamente possa ser colocado no campo do liberalismo igualitário, sua interpretação do igualitarismo, como se evidenciará na seção "Igualitarismo de fortuna", diverge sensivelmente do liberalismo rawlsiano no que se refere ao componente de justiça distributiva.

6. Note-se que um direito irrestrito de propriedade - quer de recursos externos, quer daquilo que se obtém do exercício dos próprios talentos e capacidade produtiva não é incluído entre as liberdades fundamentais. A forma de identificá-las, e de justificar normativamente a importância especial que o liberalismo igualitário lhes confere, passa por mostrar a conexão que têm com as faculdades morais (remeto o leitor ao último parágrafo da seção "Por que a igualdade importa") que as pessoas devem desenvolver e exercer em sua capacidade de cidadãos iguais. Concepções amplas do direito de propriedade (como a noção de titularidade do libertarianismo) não podem ser consideradas, como sustenta Rawls (2011: 353-354), condições para o desenvolvimento e o exercício dessas faculdades. Titularidades ou direitos legítimos de propriedade, dessa perspectiva, são aqueles que resultam de uma estrutura básica justa. Para exemplificar, suponhamos que um welfare state fortemente redistributivo seja um componente de uma estrutura básica justa. Sob esse arranjo institucional, aquilo 


\section{Álvaro de Vita}

a que as pessoas têm uma titularidade, protegida de interferências arbitrárias por parte da autoridade política, é à sua renda líquida, e não à sua renda bruta.

7. Em artigo publicado em The New York Times intitulado "Our Banana Republic", Nicholas D. Kristof (2010) comenta que essa razão passou de 42:1, em 1980, para 531:1, em 2001. Na seção "Igualitarismo de fortuna", adiante, volto a essa questão do crescimento da desigualdade econômica em países desenvolvidos como os Estados Unidos.

8. Celia Lessa Kerstenetzky (2011:138) ressalta a importância da provisão pública e universal de educação infantil de qualidade, uma política que os welfare states escandinavos já adotam há décadas, para a redução do impacto do background familiar sobre as oportunidades de vida das crianças e entende que isso pode explicar a maior eficácia que as políticas educacionais escandinavas têm, em comparação com o restante da Europa, para a redução das desigualdades econômicas. Políticas sociais desse tipo, como sustenta Kerstenetsky, bem como as de provisão pública e universal de serviços de cuidados (de crianças pequenas e idosos), além de contribuírem para a justiça social, têm efeitos positivos para o desenvolvimento econômico.

9. Ver nota 22 adiante.

10. Ao afirmar isso, não estou dizendo que nenhum progresso ocorreu na educação pública no Brasil. Nos últimos quinze anos, o acesso ao ensino fundamental foi universalizado. Também se elevou consideravelmente o acesso ao ensino médio dos jovens de 15 a 17 anos (passando de 64\%, em 1995, a 85\% em 2009), embora a proporção de jovens de 19 anos com ensino médio completo permaneça muito baixa, atingindo $45 \%$ no ano de 2007 (Veloso, 2011:216). Também houve melhorias no financiamento da educação fundamental e secundária, com a criação, primeiro do Fundo de Manutenção e Desenvolvimento do Ensino Fundamental e de Valorização do Magistério (Fundef) e, depois, do Fundo de Manutenção e Desenvolvimento da Educação Básica e de Valorização dos Profissionais da Educação (Fundeb), em 2007, e com a instituição de um sistema abrangente de avaliação da educação básica. Mas a qualidade da educação pública nos ensinos fundamental e médio permanece muito baixa e ainda não há nenhum esforço mais sistemático de expandir ou mesmo de avaliar a qualidade da educação oferecida no nível da educação infantil, que tem uma importância crucial para o desempenho escolar futuro das crianças (Veloso, 2011: 220-221; 231). Ainda não há, infelizmente, razões suficientes para qualificar o juízo incisivo expresso no texto.

11. No caso do Brasil, enquanto o rendimento mensal familiar médio per capita, no ano de 2009 , era de $\mathrm{R} \$ 764,20$, a mediana do rendimento familiar per capita era de $\mathrm{R} \$ 465,00$ (IBGE, 2010:129). Em 2009, 60\% da renda mediana corresponderia a R\$279,00. Em maio de 2011, o governo brasileiro estabeleceu a linha de pobreza extrema em R $\$$ 70,00 mensais per capita, e a linha de pobreza, em $\mathrm{R} \$ 140,00$ mensais per capita (aproximadamente metade, portanto, do que resultaria caso a definição europeia fosse adotada).

12. Esta foi sua última contribuição significativa à teoria da justiça social, antes de sua morte, em 2009.

13. Examino as relações entre democracia política e justiça social em Vita (2008: cap. 4). 
14. Considerado isoladamente, o princípio de diferença sequer seria um princípio de igualdade econômica, e sim o que Larry Temkin (2009:170-175) denomina um "princípio de prioridade" (aos mais desprivilegiados).

15. Norman Daniels (2003) interpreta de forma similar o igualitarismo de Rawls.

16. Ver nota 25 para outra linha de crítica de G. A. Cohen ao princípio de diferença.

17. Agradeço aqui ao parecerista anônimo que apontou uma imprecisão na forma como eu havia formulado esse primeiro passo da argumentação de Dworkin.

18. Esse exemplo é de Van Parijs (1995:48-54).

19. No caso do Brasil, na primeira década do século XXI, houve não somente redução nas taxas de pobreza absoluta, como também uma redução expressiva da desigualdade de renda. De acordo com uma estimativa (Soares, 2010), o coeficiente de Gini de desigualdade de renda (multiplicado por 100) caiu de 59,4 pontos em 2001 para 55,9 pontos em 2006, o que equivale a uma redução de 0,7 ponto em média por ano nesse período. Mas considerando-se que entre os fatores que explicam essas reduções estão a expansão de programas sociais como o Bolsa-Família e a política de elevação do valor real do salário mínimo (que impactou as transferências indexadas ao salário mínimo e, muito provavelmente, também os salários que estão próximos ao salário mínimo no mercado de trabalho), há dúvidas sobre a eficácia dessas políticas para garantir a continuidade dessas tendências de queda no futuro. Seriam precisos 12 anos consecutivos com essa medida de 0,7 ponto de redução ao ano do coeficiente de Gini para que o Brasil atingisse os níveis de desigualdade de renda que os Estados Unidos, o mais desigual dos países ricos da OCDE, apresentavam em 2006. E seriam necessários 24 anos com essa média anual de redução para o Brasil atingir os níveis de desigualdade de renda que o Canadá apresentava em 2006. "Se continuarmos reduzindo nosso coeficiente de Gini a 0,7 ponto ao ano pelos próximos 24 anos [de 2006 a 2030], não será possível ter grandes favelas coexistindo com condomínios de luxo, indivíduos à beira da fome no sertão do Cariri no mesmo país cujos céus são cruzados por executivos viajando na segunda maior frota de aviões particulares do mundo, nem um exército de empregados particulares passando as roupas, encerando os pisos e lavando os banheiros da classe média" (Soares, 2010: 376).

20. Raghuram Rajan, ex-economista-chefe do FMI que esteve entre os poucos de sua profissão (ao lado de Nouriel Roubini e Kenneth Rogoff) a antever e a alertar para os riscos de uma crise financeira mundial como a que eclodiu em 2007 e assumiu grandes proporções com a quebra do Banco Lehman Brothers em setembro de 2008, sustenta que o crescimento da desigualdade de renda nos Estados Unidos foi uma das causas importantes - essa é, para Rajan (2010: cap. 1), uma das "falhas geológicas da economia mundial" - da crise, que passou despercebida para a maior parte dos analistas. Conforme os rendimentos no topo disparavam, os políticos nos Estados Unidos procuraram formas de responder às angústias da classe média e da classe média baixa aqueles cujos ganhos os colocam nas proximidades do $50^{\circ}$ centil da distribuição de ganhos salariais - com os salários estagnados e com a crescente insegurança do emprego. Como não podiam elevar facilmente o salário do trabalhador mediano (Rajan acredita que fazer isso depende crucialmente de elevar a qualidade da educação, da educação pré-escolar ao ensino médio, e de elevar as oportunidades de acesso à educação superior de qualidade), os políticos dos dois principais partidos nos Estados Unidos optaram pela via de menor resistência política e deram a seus eleitorados mais para gastar, fomentando uma explosão do crédito, especialmente por meio do 
crédito imobiliário. "[...] a resposta política à crescente desigualdade - quer tenha sido cuidadosamente planejada ou uma reação não premeditada às demandas do eleitorado - foi expandir os empréstimos às famílias, especialmente as de renda baixa. Os benefícios - consumo crescente e mais empregos - foram imediatos, enquanto o pagamento da conta inevitável pôde ser postergado para o futuro. Por mais cínico que isso possa parecer, o crédito fácil tem sido utilizado como paliativo ao longo da história por governos que se mostram incapazes de enfrentar diretamente as ansiedades mais profundas da classe média" (Rajan, 2010: Introdução).

21. É o que faz o economista Antón Costas em um artigo intitulado "Quiebra moral de la economía de mercado", publicado no jornal El País de 18 de abril de 2011.

22. Norman Daniels, em vários de seus trabalhos (Daniels, 2003; 2010), empenha-se em demonstrar um ponto que simplesmente pressupus (sem argumentar) na seção "Por que a igualdade importa" deste artigo: o de que o ideal de igualdade equitativa de oportunidades tem implicações não somente para a distribuição de oportunidades educacionais e de acesso a posições ocupacionais e de responsabilidade, mas também para a garantia do acesso a serviços de saúde de qualidade. Necessidades relativas à saúde têm um peso crucial para a liberdade efetiva de uma pessoa, do modo como essa ideia de liberdade foi interpretada na mencionada seção. É preciso entender as desigualdades de condição de saúde, como Daniels enfatiza, da ótica de uma ideia de necessidades dos cidadãos, com a implicação de que essas desigualdades devem ser enfrentadas por meio de um sistema público de saúde que objetive garantir, tanto quanto possível, e de forma razoável e equitativa, o funcionamento normal dos cidadãos ao longo da vida inteira.

23. Aqui estou reformulando uma passagem de um texto anterior, no qual também analisei essa objeção de G.A. Cohen a Rawls (Vita, 2007: 165-171). Meu objetivo, ali, era fazer uma crítica ao welfarismo subjetivo. Agora me parece que a objeção de Cohen é mais bem enquadrada em uma discussão do igualitarismo de fortuna, que é a perspectiva normativa adotada por ele mesmo.

24. Ver também a seção 17 de Uma Teoria da Justiça (Rawls, 2008:124).

25. Ver os capítulos 8-10 de Cohen (2001). Nestes escritos, Cohen distingue entre uma "interpretação estrita" e uma "interpretação frouxa" do princípio de diferença da teoria de Rawls. De acordo com a interpretação estrita, as desigualdades econômicas que beneficiam aqueles que têm uma capacidade produtiva com elevado valor de mercado (os "ricos talentosos" ou high fliers, como Cohen os denomina, sem atribuir a esses termos nenhuma conotação valorativa) só são justificadas, em uma sociedade justa, caso se possa demonstrar que, sem essas desigualdades, os ricos talentosos seriam incapazes de empregar sua capacidade produtiva superior de modo a elevar o quinhão distributivo dos mais desprivilegiados, avaliando-se essa incapacidade com base em critérios outros que não as intenções que os próprios ricos talentosos escolhem ter. De acordo com a "interpretação frouxa", os incentivos geradores de desigualdades econômicas só são necessários de forma relativa às intenções e disposições que os ricos talentosos cultivam sob o status quo injusto que os beneficia. Para o princípio de diferença, em sua "interpretação estrita", ser colocado em prática, é preciso haver não somente instituições justas, mas também, e esse é o passo mais controverso dessa argumentação de Cohen, um etos informado por esse princípio - uma cultura de justiça e fraternidade na sociedade - que alcance as escolhas pessoais, especialmente as que os high fliers fazem ao decidir que uso dar, e que nível de recom- 
pensa exigir, para sua capacidade produtiva que tem valor de mercado superior. Em Vita (2008: cap. 2), sustento que a rejeição à "interpretação frouxa" do princípio de diferença não nos compromete com as implicações fortes que Cohen retira de sua "interpretação estrita", especialmente a rejeição ao alcance estritamente institucional do princípio de diferença. Mas essa discussão é ortogonal àquela que é central neste artigo, que diz respeito à interpretação das aspirações do igualitarismo pelo luck egalitarianism que Cohen, embora tenha críticas à versão de Dworkin, subscreve como princípio fundamental de justiça. Em um de seus últimos escritos (antes de sua morte, em agosto de 2009), Cohen defende o igualitarismo de fortuna como princípio fundamental de justiça política que deve ter sua validade normativa vigorosamente justificada de forma insensível a fatos (Cohen, 2009). 


\section{Álvaro de Vita}

\section{REFERÊNCIAS BIBLIOGRÁFICAS}

ANDERSON, Elizabeth S. (1999), "What is the Point of Equality?". Ethics, vol. 109, pp. 287-337.

ARNESON, Richard. (1990), “Liberalism, Distributive Subjectivism, and Equal Opportunity for Welfare". Philosophy and Public Affairs, vol. 19, pp. 158-194.

_ (1991), "A Defense of Equal Opportunity for Welfare". Philosophical Studies, vol. 62 , pp. 187-195.

ARROW, Kenneth. (1973), “Some Ordinalist-Utilitarian Notes on Rawlss Theory of Justice". Journal of Philosophy, vol. 70, no 9, pp. 245-263.

ATKINSON, Anthony, PIKETTY, Thomas e SAEZ, Emmanuel. (2011), “Top Incomes in the Long Run of History". Journal of Economic Literature, vol. 49, no 1, pp. 3-71.

BARRY, Brian. (2005), Why Social Justice Matters. Cambridge, Polity Press.

BERLIN, Isaiah. (2002), Dois Conceitos de Liberdade, in H. Hardy e R. Hausheer (orgs.), Estudos sobre a humanidade. Uma antologia de Ensaios. São Paulo, Companhia das Letras, pp. 226-272.

COHEN, G. A. (1989), "On the Currency of Egalitarian Justice". Ethics, vol. 99, pp. 906-944.

(1992), "Incentives, Inequality, and Community", in G. Peterson (org.), The Tanner Lectures on Human Values. Salt Lake City. University of Utah, pp. 261-329.

(1993), "Equality of What? On Welfare, Goods, and Capabilities". in M. Nussbaum e A. Sen (orgs.), The Quality of Life. Oxford, Clarendon Press.

. (1997), "Where the Action Is: On the Site of Distributive Justice". Philosophy and Public Affairs, vol. 26, no 1, pp. 3-30.

. (2001), If Youre an Egalitarian, How Come You're So Rich? Cambridge, Harvard University Press.

. (2009), "Facts and Principles", in T. Christiano e J. Christman (orgs.), Contemporary Debates in Political Philosophy. Oxford, Wiley-Blackwell, pp. 23-40.

DANIELS, Norman. (2003), “Democratic Equality: Rawlss Complex Egalitarianism”, in S. Freeman (org.), The Cambridge Companion to Rawls. Cambridge, Cambridge University Press, pp. 241-276.

. (2010), "Capabilities, Opportunities, and Health", in H. Brighouse e I. Roybeyns (orgs.), Measuring Justice. Primary Goods and Capabilities. Cambridge, Cambridge University Press, pp. 131-149.

DWORKIN, Ronald. (2000), Sovereign Virtue. The Theory and Practice of Equality. Cambridge, Harvard University Press.

HAYEK, Friedrich Von. (1976), Law, Legislation and Liberty. The Mirage of Social Justice. Chicago, The University of Chicago Press, vol. 2.

IBGE (Instituto Brasileiro de Geografia e Estatística). (2010), “Síntese dos Indicadores Sociais: Uma Análise das Condições de Vida da População Brasileira 2010". Estudos E Pesquisas. Informação Demográfica e Socioeconômica, vol. 27. 
FRANKFURT, Harry. (1987), "Equality as a Moral Ideal". Ethics, vol. 98, pp. 21-43.

KERSTENETZKY, Celia L. (2011), “Welfare State e Desenvolvimento”. DADOS, vol. 54, no 1, pp. 129-156.

KRISTOF, Nicholas D. (2010), “Our Banana Republic". The New York Times, 6 de novembro, p. WK10.

KYMLICKA, Will. (1990), Contemporary Political Philosophy. An Introduction. Oxford, Oxford University Press.

MURRAY, Charles. (1994[1984]). Losing Ground. American Social Policy 1950-1980. New York, Basic Books.

NAGEL, Thomas. (2003), "Rawls and Liberalism", in S. Freeman (org.), The Cambridge Companion to Rawls. Cambridge, Cambridge University Press, pp. 62-85.

NOZICK, Robert. (1974), Anarchy, State, and Utopia. New York, Basic Books.

RAJAN, Raghuram. (2010), Fault Lines: How Hidden Fractures Still Threaten the World Economy. Princeton, Princeton University Press, Kindle Edition.

RAWLS, John. (1982), “Social Unity and Primary Goods", in A. Sen e B. Williams (orgs.), Utilitarianism and Beyond. Cambridge, Cambridge University Press, 159-186..

. (2008), Uma Teoria da Justiça. São Paulo, Martins Fontes.

(2011). O Liberalismo Político (ed. Ampliada). São Paulo, Martins Fontes.

ROEMER, John. (1996), Theories of Distributive Justice. Cambridge, Harvard University Press.

SEN, Amartya. (1992), Inequality Reexamined. Cambridge, Harvard University Press. (1999), Development as Freedom. New York, Alfred Knopf.

(2009), The Idea of Justice. Cambridge, The Belknap Press of Harvard University Press.

SHAPIRO, Ian. (2003), The State of Democratic Theory. Princeton, Princeton University Press.

SOARES, Sergei Suarez Dillon. (2010), “O Ritmo na Queda da Desigualdade no Brasil É Aceitável?" Revista Brasileira de Economia Política, vol. 30, no 3, pp. 364-380.

TEMKIN, Larry S. (2009), “Illuminating Egalitarianism”, in T. Christiano e J. Christman (orgs.), Contemporary Debates in Political Philosophy. Oxford, Wiley-Blackwell, pp. 155-178.

TOCQUEVILLE, Alexis de. (2009) [1856], O Antigo Regime e a Revolução. São Paulo, Martins Fontes.

VAN PARIJS, Philippe. (1995), Real Freedom for All. What (If Anything) Can Justify Capitalism? Oxford, Clarendon Press.

VELOSO, Fernando. (2011), "A Evolução Recente e Propostas para a Melhoria da Educação no Brasil", in E. Bacha e S. Schwartzman (orgs.), Brasil: A Nova Agenda Social. Rio de Janeiro, LTC, pp. 215-253.

VITA, Álvaro de. (1999), “Justiça Distributiva: A Crítica de Sen a Rawls". DADOS, vol. 42, no 3, pp. 471-496.

. (2007), A Justiça Igualitária e seus Críticos. São Paulo, Martins Fontes.

(2008), O Liberalismo Igualitário. Sociedade Democrática e Justiça Internacional. São Paulo, Martins Fontes. 


\section{ABSTRACT \\ Liberalism, Social Justice, and Individual Responsibility}

The study examines the contemporary normative debate on social justice from the perspective of the normative political theory of "egalitarian liberalism". Contrary to an anti-egalitarian liberal political theory, or "libertarianism", the argument is that a notion of "effective freedom", and not negative freedom, is central to egalitarian liberalism. Additionally, in contrast to a theoretical current of egalitarianism known as "luck egalitarianism", the article further argues that although egalitarian liberalism assigns special importance to individual responsibility, it does so (unlike "luck egalitarianism") without implying any concession to the conservative critique of egalitarianism and the state's redistributive action.

Key words: egalitarian liberalism; social justice; luck egalitarianism; individual responsibility

\section{RÉSUMÉ}

\section{Libéralisme, Justice Sociale et Responsabilité Individuelle}

Dans cet article, on examine le débat normatif contemporain sur la justice sociale dans l'optique de la théorie politique normative du "libéralisme égalitaire". En opposition avec une théorie politique libérale anti-égalitaire, le libertarianisme, on propose que la notion de "liberté effective" et non pas de liberté négative, est centrale pour le libéralisme égalitaire. Et, en opposition avec un versant théorique de l'égalitarisme nommé luck egalitarianism, on soutient que, bien que le libéralisme égalitaire donne une importance particulière à la responsabilité individuelle, il le fait de façon que, à l'inverse de ce qui se passe avec l'"égalitarisme de la fortune", cela n'implique aucun renoncement à la critique conservatrice à propos de l'égalitarisme et de l'action redistributive de l'État.

Mots-clés: libéralisme égalitaire; justice sociale; luck egalitarianism; responsabilité individuelle 